Vol. 1 No. 1 September 2021, e-ISSN : 2807-8667| p-ISSN : 2807-8837

\title{
UPAYA MENINGKATKAN MOTIVASI BELAJAR SISWA PADA MATA PELAJARAN GEOGRAFI DENGAN MODEL PEMBELAJARAN GUIDED DISCOVERY PADA SMAN 9 KOTA JAMBI
}

\author{
TIGWANDI \\ SMA Negeri 9 Kota Jambi Provinsi Jambi \\ tigwandi110@gmail.com
}

\begin{abstract}
ABSTRAK
Penelitian ini bertujuan untuk: 1) mengetahui bagaimana gambaran motivasi belajar geografi siswa dengan menggunakan model pembelajaran Guided Discovery di kelas XII SMA Negeri 9 Kota Jambi. 2) mengetahui peningkatan motivasi belajar geografi dengan menggunakan model pembelajaran Guided Discovery di kelas XII SMA Negeri 9 Kota Jambi. Sasaran dalam penelitian ini adalah siswa kelas XII IPS-2 SMA Negeri 9 Kota Jambi yang berjumlah 35 siswa. Jenis penelitian yang digunakan adalah Penelitian Tindakan Kelas (PTK). Penelitian ini Terdiri dari 2 siklus dimana setiap siklus terdiri dari tiga pertemuan. Pertemuan ke-1 dan ke-2 merupakan pemberian materi dan pertemuan ke-3 adalah evaluasi akhir siklus. Motivasi penelitian ini menunjukkan 1) Rerata motivasi belajar siswa sebelum menggunakan model pembelajaran Guided Discovery adalah 40,67. Kemudian meningkat setelah penerapan model pembelajaran Guided Discovery pada siklus I sebesar 63,267 termasuk dalam kategori sedang, dan pada siklus II sebesar 75,33 juga termasuk dalam kategori sedang dengan persentase peningkatan 13,79\%.2) Motivasi observasi aktivitas siswa dalam proses belajar mengajar juga terjadi peningkatan, pada siklus I pertemuan pertama sebesar $60,14 \%$ kemudian mengalami peningkatan pada pertemuan kedua sebesar $68,88 \%$. Pada siklus II pertemuan ke-1 sebesar $70,83 \%$ dan mengalami perubahan pada pertemuan ke-2 sebesar $78,47 \%$ termasuk dalam kategori "sangat aktif".
\end{abstract}

Kata Kunci: motivasi belajar, geografi, guided discovery.

\section{PENDAHULUAN}

Pendidikan adalah sebuah wadah mapan dalam meningkatkan kompetensi, keterampilan dan aspek lainnya dalam meningkatkan nilai kehidupan manusia. Pendidikan merupakan pokok dasar sebagai bekal peningkatan sumber daya manusia (SDM) yang mumpuni. Pendidikan menciptakan pembelajaran yang merupakan unsur dalam kegiatan mendapatkan pengetahuan. Pembelajaran merupakan aspek kegiatan manusia yang kompleks. Pembelajaran secara sederhana dapat didefinisikan sebagai produk interaksi berkelanjutan antara pengembangan dan pengalaman hidup. Dalam makna yang lebih komprehensif, hakikatnya pembelajaran adalah usaha sadar dari seorang pendidik untuk membelajarkan siswanya dalam rangka mencapai tujuan pembelajaran yang diharapkan (Purwati, 2014). Pada praktek pendidikan era sekarang ini, proses pembelajaran abad 21 menuntut kompetensi lulusan berkualitas dan unggul serta mampu bersaing di era global ((Ningsih et al., 2020). Lebih lanjut, (Nurjannah et al., 2020) mengungkapkan bahwa pendidikan merupakan kebutuhan penting yang menjadi faktor utama dalam mencerdaskan kehidupan bangsa dan Negara. Untuk itu peningkatan kualitas sumber daya manusia dapat dicapai salah satunya dengan penekanan pada bidang pendidikan. Dapat dimaknai bahwa pendidikan mempunyai kontribusi yang sangat besar bagi kemajuan dan pembangunan suatu bangsa.

Berbagai upaya telah dilakukan pemerintah untuk memperbaiki sistem pendidikan Indonesia. Salah satunya dengan selalu melakukan pembaruan dan perubahan kurikulum mengikuti teknologi di masa perkembangan zaman yang ada. Hal tersebut diungkapkan oleh (Ridsa et al., 2020) bahwa kepribadian siswa yang dipengaruhi oleh perkembangan teknologi tentu juga berdampak pada pendidikan. Hal yang paling dibutuhkan dalam proses belajar mengajar adalah kreativitas seorang guru dalam mengajar sehingga pembelajaran menjadi menarik. Kegiatan belajar yang dilaksanakan haruslah berpusat pada siswa, guru hanya sebagai 
motivator dan fasilitator, dan guru harus bisa mendorong peerta didik agar dapat belajar mengkonstruksi sendiri pengetahuannya melalui berbagai aktivitas belajar. Sehingga saat siswa diberi kesempatan untuk mengkonstruksi pengetahuannya sendiri siswa dengan mudah akan memahami konsep-konsep yang diajarkan. Untuk itu diperlukan sebuah teknik pembelajaran yang bisa mendorong siswa dalam mengkonstruksi materi diterima di sekolah dan disesuaikan dengan pengalaman siswa, sehingga dengan mudah dapat memahami konsep-konsep yang diajarkan. Teknik peta pikiran merupakan teknik pembelajaran yang tidak mengharuskan siswa menghafal fakta-fakta, tetapi sebuah teknik pembelajaran yang mendorong siswa mengkontruksikan suatu konsep dibenak mereka sendiri (Harjanti, 2014).

Proses belajar mengajar mencakup komponen, pendekatan, dan berbagai model pembelajaran yang dikembangkan dalam proses tersebut. Tujuan utama diselenggaranya proses belajar mengajar adalah demi tercapainya tujuan pembelajaran. Tercapainya tujuan pembelajaran dapat ditentukan oleh berbagai faktor, diantaranya adalah profesionalisme tenaga pendidik, model pembelajaran, metode pembelajaran yang digunakan, fasilitas sekolah dan masih banyak faktor yang lainnya. Semua faktor memiliki peranan yang sama pentingnya dalam menentukan kebermotivasian proses pembelajaran. Salah satu faktornya adalah profesionalisme guru, dimana guru dituntut untuk mampu menerapkan berbagai model pembelajaran yang ada. Dalam penerapan model pembelajaran tersebut harus memerhatikan berbagai kondisi seperti karakter siswa, keadaan lingkungan sekolah serta berbagai faktor lainnya demi mendapatkan kebermotivasian pembelajaran yang diinginkan serta sesuai standar (Duhita dan Hasriyanti, 2020).

Guna memaksimalkan penguasaan materi pada proses pembelajaran, maka dibutuhkan motivasi yang tinggi bagi siswa agar selalu memiliki semangat dan rasa gairah yang tinggi dalam mengikuti setiap materi yang diajarkan. Motivasi menjadi satu faktor yang mempengaruhi prestasi siswa. Proses pembelajaran akan bermotivasi manakala siswa mempunyai motivasi dalam belajar. Oleh karena itu, guru perlu menumbuhkan motivasi belajar siswa. Untuk memperoleh motivasi belajar yang optimal, guru dituntut kreatif membangkitkan motivasi belajar siswa (Suprihatin, 2015). Dengan adanya motivasi, siswa akan belajar lebih keras, ulet, tekun dan memiliki dan memiliki konsentrasi penuh dalam proses belajar pembelajaran. Dorongan motivasi dalam belajar merupakan salah satu hal yang perlu dibangkitkan dalam upaya pembelajaran di sekolah (Kusuma dan Subkhan, 2015).

Biggs dan Tefler (dalam Dimyati dan Mudjiono, 2006) mengungkapkan motivasi belajar siswa dapat menjadi lemah. Lemahnya motivasi atau tiadanya motivasi belajar akan melemahkan kegiatan, sehingga mutu prestasi belajar akan rendah. Oleh karena itu, mutu prestasi belajar pada siswa perlu diperkuat terus-menerus. Dengan tujuan agar siswa memiliki motivasi belajar yang kuat, sehingga prestasi belajar yang diraihnya dapat optimal. Motivasi belajar yang dimiliki siswa dalam setiap kegiatan pembelajaran sangat berperan untuk meningkatkan prestasi belajar siswa dalam mata pelajaran tertentu (Nashar, 2004:11). Siswa yang bermotivasi tinggi dalam belajar memungkinkan akan memperoleh motivasi belajar yang tinggi pula, artinya semakin tinggi motivasinya, semakin intensitas usaha dan upaya yang dilakukan, maka semakin tinggi prestasi belajar yang diperolehnya.

Sardiman (2011:73) mengatakan bahwa motivasi belajar adalah dorongan dalam kegiatan belajar, sehingga motivasi dapat dikatakan sebagai daya penggerak dalam diri siswa yang menimbulkan kegiatan belajar supaya tujuan yang dikehendaki oleh subjek belajar itu dapat dicapai. Cara dalam peningkatan motivasi dalam belajar adalah 1) lama kegiiatan. 2) intensitas kegiaatan. 3) presistensi pada tujan kegiiatan. 4) tabah, ulet dan mampu dalam menghadapi berbagai rintangan dalam mencapai sebuah tujuan. 5) dalam mencapai tujuan perlu pengabdian dan pengorbanan. 6) kegiatan yang dilakukan dengan tingkatan aspriasi yang hendak dicapai 7) jenjang kualifikasi prestasi. 8) sasaran pada kegiatan tergantung pada arah sikap (Pratama dan Neviyarni, 2019).

Penerapan model pembelajaran di sekolah masih menemui banyak permasalahan, khususnya dalam mata pelajaran geografi. Materi ajar pada geografi yang banyak disetiap 
pokok bahasan, namun alokasi waktu yang ada sedikit menyebabkan guru lebih memilih memberikan tugas kepada siswa dalam bentuk meringkas materi dengan tujuan siswa akan lebih mudah memahami konsep yang ada pada materi yang sedang diajarkan tanpa menjelaskan lebih rinci materi tersebut. Namun yang terjadi siswa merasa belum paham dengan materi pokok yang ada sudah harus memulai lagi dengan materi yang baru. Hal ini menyebabkan timbulnya rasa jenuh, tidak bersemangat dalam proses belajar mengajar, serta siswa tidak tertarik dengan materi yang disampaikan oleh guru. Selain itu guru juga sering mendiktekan materi ajar kepada siswa dan tugas yang diberikan adalah menghafal. Hal ini sejalan dengan penjelasan yang dipaparkan oleh Aritonang (2008) yang menyebutkan bahwa kenyataan lain menunjukkan guru dalam proses belajar-mengajar hanya memberikan materi pelajaran saja. Guru jarang sekali memberikan motivasi pada siswa dalam mengajar. Hal ini disebabkan banyaknya jumlah pokok bahasan yang harus diajarkan sehingga guru cenderung hanya memberikan materi saja tanpa berusaha membangkitkan minat dan motivasi belajar siswa. Pembelajaran akan berlangsung efektif apabila siswa memiliki motivasi dalam belajar. Guru harus berupaya secara maksimal agar siswa termotivasi untuk belajar. Oleh karena itu motivasi belajar menjadi salah satu kunci kebermotivasian dalam mencapai tujuan pembelajaran. Motivasi belajar harus dibangkitkan dalam diri siswa sehingga siswa termotivasi dalam belajar (Emda, 2018).

Berdasarkan survey peneliti di SMA Negeri Negeri 9 Kota Jambi ditemukan beberapa kendala pada proses pembelajaran. Pertama, pembelajaran Geografi banyak mengandung prinsip, konsep, dan teori yang abstrak sulit dipahami oleh siswa. Kedua, siswa kurang optimal saat mengikuti pembelajaran sehingga pemahaman konsep siswa kurang baik dan berakibat siswa hanya menghafal materi. Ketiga siswa menganggap pembelajaran Geografi sebagai hal yang sulit untuk dipelajari sehingga pada proses pembelajaran siswa kurang antusias. Beberapa kendala tersebut mengakibatkan banyak siswa yang memperoleh motivasi belajar kurang dari batas ketuntasan belajar siswa. Motivasi studi pendahuluan yang dilakukan di SMA Negeri Negeri 9 Kota Jambi Kelas XII IPS-2 diketahui bahwa ketuntasan klasikal siswa belum mencapai $85 \%$. Berdasarkan latar belakang permasalahan tersebut, maka salah satu model pembelajaran yang dapat digunakan untuk mengkonstruksikan pemikiran siswa dalam memecahkan masalah adalah Guided Discovery Learning.

Untuk memecahkan permasalahan pembelajaran yang demikian perlu dilakukan upaya antara lain berupa perbaikan strategi pembelajaran yaitu mengubah model pembelajaran yang dapat memfasilitasi terjadinya komunikasi antara siswa dengan siswa dan guru dengan siswa, sehingga mampu menumbuhkan berpikir kritis siswa. Salah satunya adalah model pembelajaran Guided Discovery (Sulistyowati, dkk, 2012). Model pembelajaran discovery merupakan kegiatan pembelajaran yang melibatkan secara maksimal seluruh kemampuan siswa untuk mencari dan menemukan sesuatu (benda, manusia, atau peristiwa) secara sistematis, kritis, logis, analitis sehingga mereka dapat merumuskan sendiri penemuanya dengan penuh percaya diri. Pembelajaran discovery memiliki kelebihan yaitu menjadikan siswa lebih aktif dalam pembelajaran, siswa dapat memahami benar konsep yang telah dipelajari, jawaban yang diperoleh akan menimbulkan rasa puas pada siswa (Purwanto dan Nugroho, 2012).

Menurut Mayer (2004), Guided Discovery Learning merupakan salah satu model pembelajaran yang bertujuan melatih siswa untuk menemukan konsep secara mandiri. Siswa berperan aktif dalam proses pembelajaran dengan menjawab berbagai pertanyaan atau persoalan dan memecahkan persoalan untuk menemukan suatu konsep. Di dalam Guided Discovery Learning, guru menyajikan contoh-contoh, memandu untuk menemukan pola-pola dalam contoh-contoh tersebut, dan memberikan kesimpulan ketika siswa telah mampu mendeskripsikan gagasan yang telah di ajarkan oleh guru (Jacobson, dkk. 2009).

Guided discovery merupakan suatu cara untuk mengembangkan cara belajar aktif. Siswa menyelidiki berdasarkan pengalaman dan pengetahuan awal mereka, untuk menemukan kebenaran atau pengetahuan baru yang harus dipelajari. Berdasarkan pengertian guided discovery di atas dapat disimpulkan bahwa pembelajaran guided discovery adalah suatu kegiatan penyelidikan melalui tukar pendapat, dengan diskusi, seminar, membaca sendiri, 
mencoba sendiri sehingga menemukan konsep sendiri, guru bertugas untuk memberikan bimbingan dan mengawasi proses penyelidikan. Model pembelajaran guided discovery ini dapat menjadikan siswa aktif selama prosespembelajaran, sedangkan guru bertindak sebagai fasilitator yang bertugas mengatur jalannya pembelajaran (Adhim, 2015).

Motivasi penelitian yang dilakukakan oleh Aini (2011) telah membuktikan bahwa dengan menerapkan guided discovery dapat meningkatkan motivasi belajar dan kemampuan komunikasi ilmiah siswa. Sejalan dengan Aini, penelitian yang dilakukan oleh Mayer (2004) menyimpulkan bahwa guided discovery learning lebih efektif daripada pure discovery dalam membantu proses transfer dan belajar siswa. Penelitian lain oleh Olufunmilayo (2010) menyimpulkan bahwa guided discovery sangat baik dalam meningkatkan prestasi kimia siswa.

\section{METODE PENELITIAN}

Jenis penelitian ini merupakan penelitian tindakan kelas (PTK). Tahap-tahap penelitian dalam penelitian tinda kelas meliputi perencanaan (planning), pelaksaan/tindakan (action), pengamatan (observation), dan refleksi (reflection), yang dirangkaikan ke dalam satu siklus kegiatan (Sanjaya, 2016). Penelitian ini dilakukan di SMA Negeri 9 Kota Jambi pada tahun pelajaran 2020/2021. Adapun subjek penelitian ini adalah siswa kelas XII IPS-2 di SMA Negeri 9 Kota Jambi yang berjumlah 35 siswa.

Teknik pengumpulan data yang akan digunakan pada penelitian ini adalah yang pertama instrumen observasi yang digunakan pada penelitian ini berupa lembar observasi terstruktur. Lembar observasi ini terdiri atas lembar observasi aktivitas peserta didik selama kegiatan pembelajaran berlangsung. Lembar obsevasi ini digunakan untuk menentukan langkah selanjutnya setelah kegiatan pembelajaran menggunakan model Guided Discovery Learning. Kedua, instrumen tes digunakan untuk mengukur tingkat kebermotivasian peserta didik selama mengikuti kegiatan pembelajaran terdiri atas beberapa soal pilihan ganda dan uraian. Instrumen yang digunakan berupa soal-soal latihan yang mengacu pada tujuan pembelajaran yang hendak dicapai dalam pembelajaran. Dan yang terakhir adalah teknik dokumentasi.

Aktivitas peserta didik selama proses belajar mengajar berlangsung dianalisi secara kualitatif berdasarkan aspek yang telah ditentukan. Kriteria penilaian yang digunakan untuk menetukan tingkat kebermotivasian dalm penilaian mengacu pada teknik kategorisasi keaktifan belajar (Nur, 2018) dengan rumus:

Persenstase Nilai Rata-Rata (NR): $\frac{\text { skor total }}{\text { skor maksimal }} \times 100 \%$

\begin{tabular}{cc}
\hline Kategori & Interval \\
\hline Kurang aktif & $<25 \%$ \\
Cukup aktif & $25 \%-50 \%$ \\
Aktif & $51 \%-74 \%$ \\
Sangat aktif & $\geq 75 \%$ \\
\hline
\end{tabular}

Sumber: (Nur, 2018)

\section{MOTIVASI DAN PEMBAHASAN}

\section{Siklus I}

Pada siklus I ini, terdapat 4 tahapan yang dilalui yaitu perencanaan pelaksanaan, observasi dan evaluasi serta refleksi. Siklus satu terdiri dari tiga pertemuan, yaitu pertemuan 1 dan 2 adalah pelaksanaan pemberian materi, dan pertemuan 3 merupakan evaluasi akhir siklus.

Pada siklus I dilaksanakan tes motivasi belajar untuk mengukur kemampuan peserta didik mengenai materi yang diberikan. Evaluasi yang diberikan berupa soal pilihan ganda 20 nomor. Berikut nilai motivasi belajar peserta didik pada siklus I dengan materi lapisan litosfer, siklus batuan, endogen dan tektonisme, serta proses dengan penerapan model pembelajaran guided discovery learning dapat dilihat pada tabel berikut: 
Tabel 1. Distribusi Nilai Motivasi Belajar Geografi Peserta Didik

\begin{tabular}{lcr}
\hline No & Data penelitian & Nilai Statistik \\
\hline 1 & Subjek & 35 \\
2 & Skor Ideal & 100 \\
3 & Nilai Terendah & 40 \\
4 & Nilai Tertinggi & 85 \\
5 & Rentang Skor & 45 \\
6 & Rata-rata Skor & 63,167 \\
\hline
\end{tabular}

Dari data di atas, dapat dilihat bahwa rerata motivasi belajar peserta didik pada siklus I dengan penerapan model pembelajaran guided discovery learning adalah 63,167 dari skor ideal yang kemungkinan dapat diraih adalah 100 . Nilai terendah yang didapat peserta didik adalah 40 dan nilai tertinggi adalah 85 , dimana dari motivasi nilai terendah dan tertinggi, didapatkan rentag skor 45. Jumlah peserta didik yang menjadi subjek pada siklus I adalah 35 peserta didik.

Tabel 2. Distribusi Frekuensi Dan Persentase Kategori Hasil Belajar Peserta Didik

\begin{tabular}{lllll}
\hline No & \multicolumn{1}{c}{ Skor } & Kategori & \multicolumn{1}{c}{ Frekuensi } & \multicolumn{1}{c}{ Persentase } \\
\hline 1 & $<55$ & Sangat Rendah & 14 & 36,66 \\
2 & $55-59$ & Rendah & 0 & 0 \\
3 & $60-75$ & Sedang & 16 & 46,67 \\
\hline 4 & $76-86$ & Tinggi & 5 & 16,67 \\
\hline 5 & $86-100$ & Sangat Tinggi & 0 & 0 \\
\hline & Jumlah & & 35 & 100
\end{tabular}

Dari tabel 2 di atas, menujukkan bahwa skor motivasi belajar pada siklus I peserta didik sangat bervariasi. Jika rerata hasil belajar peserta didik 59,83, maka motivasi belajar peserta didik pada siklus I dikategorikan "sedang “. Selanjutnya motivasi belajar peserta didik pada siklus I dinalisis maka presentasi ketuntasan klasikal belajar peserta didik pada siklus I dapat dilihat pada tabel berikut:

Tabel 3. Persentase Ketuntasan Klasikal Belajar Peserta Didik

\begin{tabular}{lllll}
\hline & KKM & \multicolumn{1}{c}{ Kategori } & Frekuensi & Persentase \\
\hline$<75$ & Tidak Tuntas & 22 & 63,33 \\
$\geq 75$ & Tuntas & 13 & 36,67 \\
\hline
\end{tabular}

Pada tabel 3 menunujukkan data presentase ketuntasan klasikal belajar peserta didik pada siklus I dengan model pembelajaran guided discovery learning. Dimana sebanyak 22 peserta didik atau sejumlah 63,33\% belum mencapai KKM yaitu 75. Dan selebihnya yaitu 13 peserta didik atau sejumlah 36,67\% tuntas secara klasikal. Peserta didik yang masih belum mencapai KKM akan diusahakan pada siklus berikutnya.

Adapun aktivitas peserta didik pada saat proses pembelajaran berlangsung selama penerapan model pembelajaran guided discovery learning pasa siklus I dapat dilihat pada lembar observasi aktivitas belajar peserta didik pada setiap pertemuan yang diamati oleh guru mata pelajaran geografi selaku observer. Pada hasil penelitian ini menggunakan teknik analisis deskriptif yang bertujuan melihat dan memberikan gambaran mengenai hasil penelitian secara jelas yang dapat berupa tabel, grafik dan uraian. Maka untuk melihat secara jelas peningkatan aktivitas peserta didik pada siklus I pertemuan pertama dan kedua maka ditampilkan diagram sebagai berikut: 
Gambar 1. Diagram Peningkatan Aktivitas Peserta Didik Siklus I

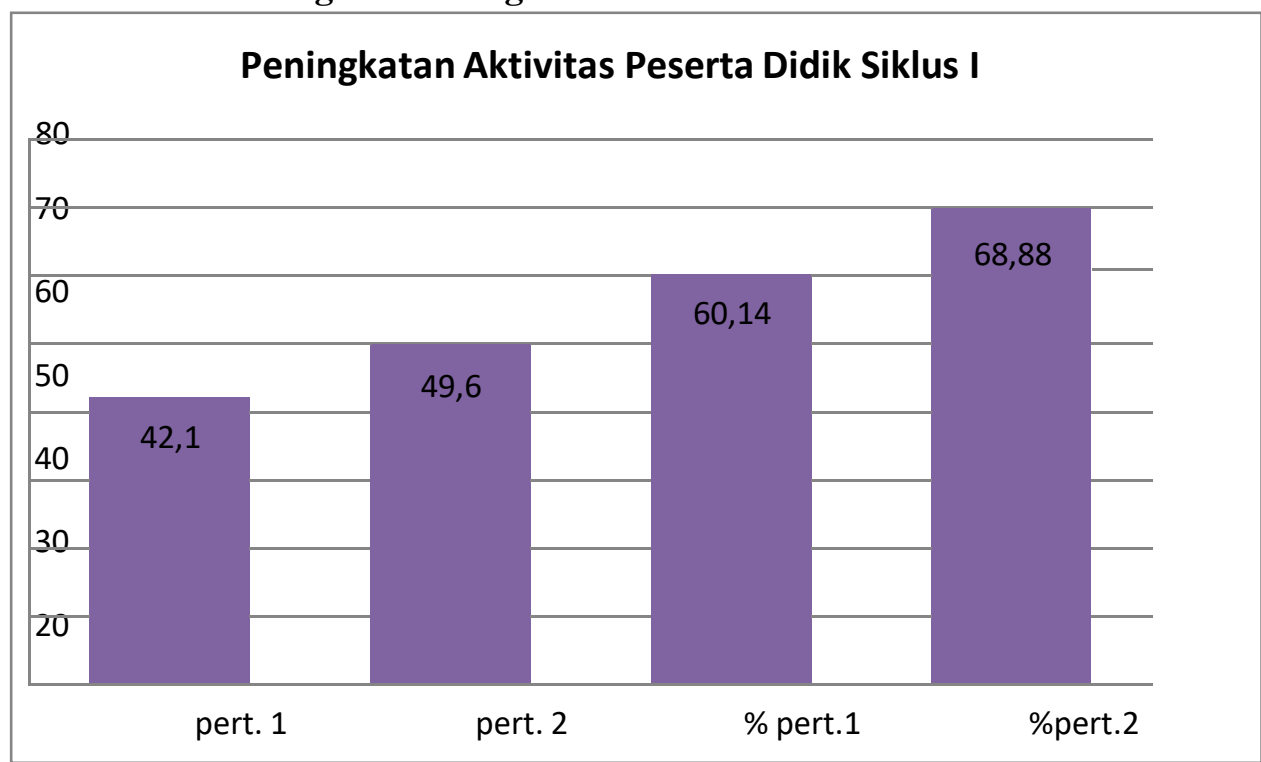

Diagram di atas menujukkan bagaimana peningkatan aktivitas peserta didik selama proses pembelajaran dengan menerapkan model guided discovery learning. Pada pertemuan pertama siklus I peserta didik mendapat skor 42,2 dari skor maksimal yang mungkin didapat yaitu 72 atau setara dengan 60,14\% angkat tersebut sudah masuk dalam kategori sedang/cukup. Sedangkan pada pertemuan kedua mengalami peningkatan sebesar 49,6 atau 68,88\% yang sudah masuk dalam kategori baik.

Berdasarkan pelaksanaan tindakan siklus I dengan menggunakan model pembelajaran guided discovery learning masih menemuai berbagai permasalahan sehingga belum mendapatkan hasil yang maksimal diantaranya: a) Peserta didik masih kurang antusias dalam pembelajaran. b) Kurangnya antusias peserta didik ketika dilontarkan pertanyaan. c) Peserta didik masih bingung ketika dihadapkan dengan permasalahan. d) Perhatian peserta didik masih terbagi dengan hal lain ketika proses pembelajaran berlangsung. e) Kurangnya kesadaran peserta didik untuk bekerjasama dengan kelompoknya. f) Beberapa peserta didik masih segan untuk melontarkan pertanyaan.

\section{Siklus II}

Pelaksanaan tindakan pada siklus II merupakan pengulangan langkah kerja terhadap siklus sebelumnya, pada siklus ini, telah mengalami perbaikan dan pengembangan terhadap kekurangan yang ada apa siklus sebelumnya disesuaikan pada hasil refleksi siklus I. Adapun kegiatan yang dilakukan pada siklus ini juga diulangi secara bertahap seperti pada siklus sebelumnya juga mungkin terjadi. Siklus II dilakukan pada pertemuan 4 dan 5 sebagai pemberian materi, dan pertemuan 6 yang merupakan evaluasi akhir siklus.

Motivasi belajar pada peserta didik kelas XII IPS 2 SMA Negeri 9 Kota Jambi pada materi seisme dan proses pembentukan tanah dengan penerapan model pembelajaran guided discovery learning pada siklus II merupakan pengulangan dari siklus sebelumnya baik dari segi tahapan perencanaan, pelaksanaan, observasi, evaluasi dan refleksi, yang berpatokan pada kondisi yang ditemukan pada siklus sebelumnya, kekurangan-kekurangan yang ada pada siklus sebelumnya kemudian dikembangkan pada siklus II dengan materi yang belum diajarkan. Berikut tabel distribusi nilai hasil belajar peserta didik setelah penerapan model pembelajar guided discovery learning.

Tabel 4. Distribusi Nilai Motivasi Belajar Geografi Peserta Didik Kelas Siklus II

\begin{tabular}{ccc}
\hline No & Data penelitian & Nilai Statistik \\
\hline 1 & Subjek & 35
\end{tabular}




$\begin{array}{llc}2 & \text { Skor Ideal } & 100 \\ 3 & \text { Nilai Terendah } & 55 \\ 4 & \text { Nilai Tertinggi } & 90 \\ 5 & \text { Rentang Skor } & 35 \\ 6 & \text { Rata-rata Skor } & 75,33\end{array}$

Dari data di atas, dapat dilihat bahwa rerata motivasi belajar peserta didik pada siklus I dengan penerapan model pembelajaran guided discovery learning adalah 75,33 dari skor ideal yang kemungkinan dapat diraih adalah 100 . Nilai terendah yang didapat peserta didik adalah 55 dan nilai tertinggi adalah 90, dimana dari hasil nilai terendah dan tertinggi, didapatkan rentag skor 35. Jumlah peserta didik yang menjadi subjek pada siklus II adalah 35 peserta didik.

Tabel 5. Distribusi Frekuensi dan persentase Kategori Motivasi belajar Siklus II

\begin{tabular}{lclcc}
\hline No & Skor & Kategori & Frekuensi & Persentase \\
\hline 1 & $<55$ & Sangat Rendah & 0 & 0 \\
2 & $55-59$ & Rendah & 2 & 3,33 \\
3 & $60-75$ & Sedang & 19 & 56,66 \\
4 & $76-86$ & Tinggi & 12 & 36,67 \\
5 & $86-100$ & Sangat Tinggi & 2 & 3,33 \\
\hline \multicolumn{2}{c}{ Jumlah } & 35 & 100 \\
\hline
\end{tabular}

Dari tabel di atas menujukkan bahwa skor motivasi belajar pada siklus I peserta didik sangat bervariasi. Jika rerata hasil belajar peserta didik 75,33 maka motivasi belajar peserta didik pada siklus II dikategorikan "sedang “. Selanjutnya motivasi belajar peserta didik pada siklus II dinalisis maka presentasi ketuntasan klasikal belajar peserta didik pada siklus II dapat dilihat pada tabel berikut:

Tabel 6. Persentase Ketuntasan Klasikal Belajar Peserta Didik Siklus I

\begin{tabular}{cccc}
\hline KKM & Kategori & Frekuensi & Persentase \\
\hline$<75$ & Tidak Tuntas & 9 & 23,33 \\
$\geq 75$ & Tuntas & 26 & 76,67 \\
\hline
\end{tabular}

Pada tabel di atas menunujukkan data presentase ketuntasan klasikal belajar peserta didik pada siklus II dengan model pembelajaran guided discovery learning. Dimana sebanyak 9 peserta didik atau sejumlah 23,33\% belum mencapai KKM yaitu 75. Dan selebihnya yaitu 26 peserta didik atau sejumlah $76,67 \%$ tuntas.

Dari data di atas, menunjukkan bahwa terjadi peningkatan motivasi belajar peserta didik dari siklus I ke siklus II, dimana presentasi ketuntasan motivasi belajar peserta didik secara klasikal mengalami peningkatan walaupun pada siklus II masih terdapat 23,33\% peserta didik yang nilainya di bawah KKM. Namun hal tersebut menunjukkan terdapat perubahan dan peningkatan motivasi belajar. Itu artinya, terdapat perbaikan dan peningkatan peserta didik dalam memahami materi yang diajarkan malalui penerapan model pembelajarn guided discovery learning sehingga tidak perlu lagi dilanjutkan ke siklus selanjutnya.

Selanjutnya kan diperlihatan peningkatan hasil belajar peserta didik sebelum menggunakan model pembelajaran guided discovery learning (pretest) dan setelah diterapkannya model pembelajaran guided discovery learning pada siklus I materi lapisan litosfer, siklus batuan, tenaga endogen dan eksogen, serta tektonisme, siklus dan siklus II materi vulkanisme dan seisme. Yang dapat dilihat pada tabel berikut ini: 
Tabel 7. Perbandingan Hasil Belajar Geografi Peserta Didik Sebelum dan Sesudah menerapkan Model guided discovery learning

\begin{tabular}{llllll}
\multicolumn{1}{c}{ Siklus } & \multicolumn{3}{c}{ Nilai Yang di Peroleh 35 Peserta Didik } & Ketuntasan \\
\hline & Minimal & Maksimal & Mean & Tidak Tuntas & Tuntas \\
Sebelum & 20 & 70 & 45 & 35 & 0 \\
menerapkan & & & & & \\
$\begin{array}{l}\text { Discovery } \\
\text { Siklus 1 }\end{array}$ & 40 & 85 & 62,5 & 19 & 16 \\
Siklus 2 & 55 & 90 & 72,5 & 7 & 28 \\
\hline
\end{tabular}

Dari tabel di atas, dapat dilihat perbandingan hasil belajar peserta didik sebelum dan setelah menerapkan model pembelajar guided discovery learning kemudian selanjutnya akan dihitung presentase peningkatan hasil belajar geografi peserta didik kelas XII IPS 2 dengan menggunakan rumus:

Berdasarkan hasil deskriptif dan nilai rata-rata sebelum dan sesudah menerapkan model pembelajaran guided discovery learning pada siklus I dan siklus II di atas, menujukkan bahwa presentase peningkatan hasil belajar peserta didik adalah $13,79 \%$.

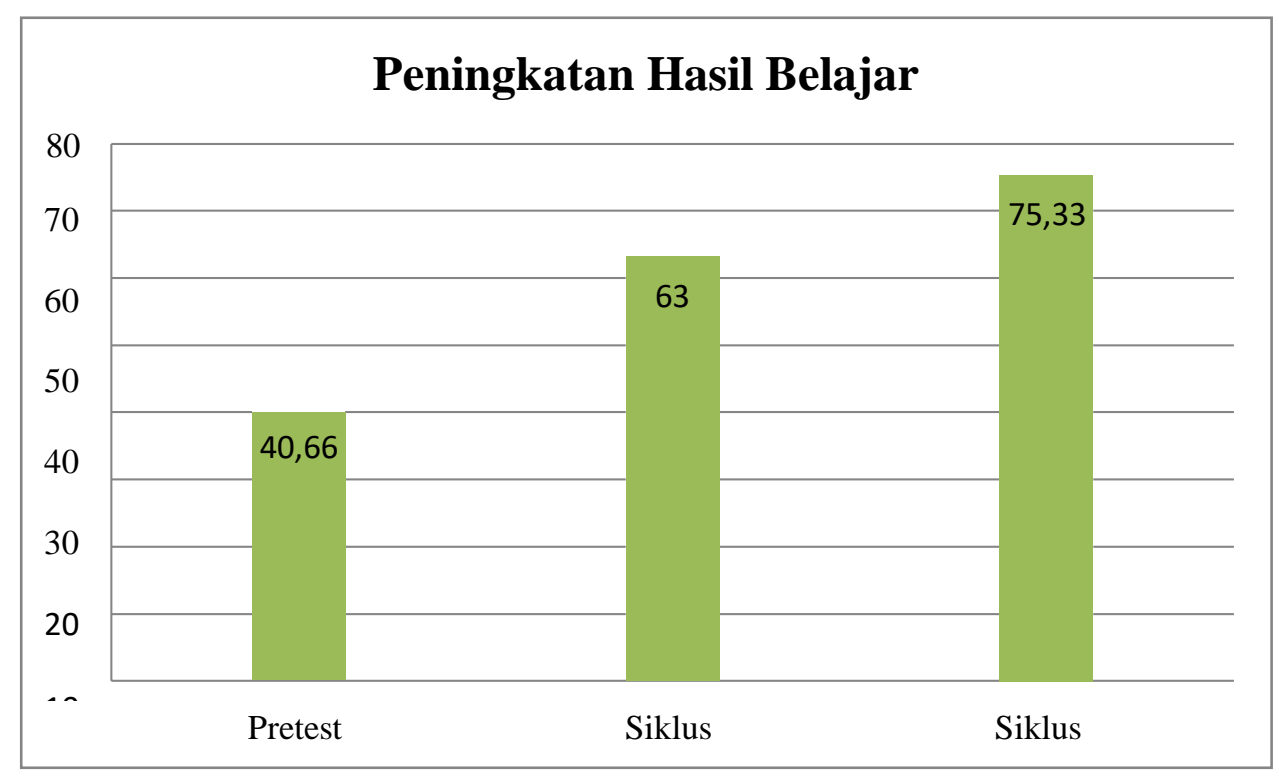

Gambar 2. Diagram Peningkatan Hasil Belajar

Gambar di atas menujukkan peningkatan rerata hasil belajar peserta didik sebelum dan sesudah menerapkan model guided discovery learning. Dimana rerata nilai pada pretest yaitu 40,167 kemudian mengalami peningkatan pada siklus I sebesar 62,5 dan pada siklus II yaitu 72,5 dengan presentase peningkatan sebesar $13,79 \%$.

Dari siklus I dan siklus II terjadi sejumlah perubahan sikap peserta didik terjadi selama penelitian berlangsung. Perubahan-perubahan tersebut terangkum dalam lembar aktivitas peserta didik yag diisi oleh penulis selaku guru mata pelajaran geografi selama proses pembelajaran berlangsung.

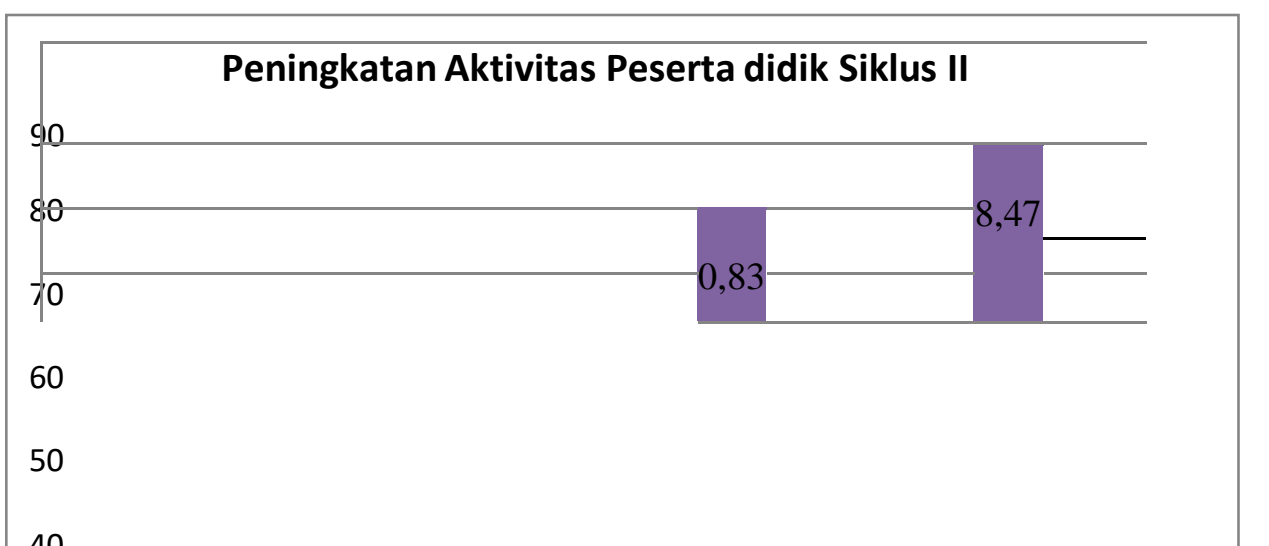




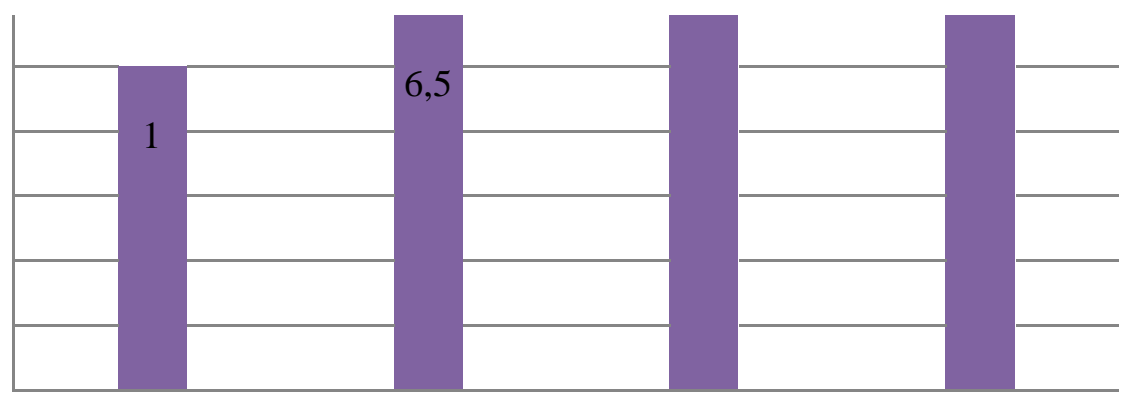

\section{Gambar 3. Diagram Peningkatan Aktivitas Peserta Didik Siklus II}

Diagram di atas menujukkan bagaimana peningkatan aktivitas peserta didik selama proses pembelajaran dengan menerapkan model guided discovery learning. Pada pertemuan pertama siklus I peserta didik mendapat skor 51 dari skor maksimal yang mungkin didapat yaitu 72 atau setara dengan $70,83 \%$ angkat tersebut sudah masuk dalam kategori sedang/cukup. Sedangkan pada pertemuan kedua mengalami peningkatan sebesar 56,5 dariskor maksimal yang mungkin di dapat adalah 72 atau $68,88 \%$ yang sudah masuk dalam kategori baik.

Adapun refleksi pertemuan pada siklus II didapatkan bahwa: a) Peserta didik antusias dalam mengikuti proses pembelajaran. b) Peserta didik mampu merancang pemecahan masalah yang ditemukannya. c) Peserta didik focus mengikuti proses pembelajaran sampai selesai. d) Peserta didik bekerjasama dengan baik dengan teman kelompoknya. e) Peserta didik aktif berdiskusi serta melontarkan pertanyaan kepada kelompok lain.

Berdasarkan tindakan yang dilakukan pada siklus II berupa perencanaan, pelaksanaan tindakan, observasi serta refleksi. Hasil dari upaya peningkatan hasil belajar peserta didik melalui penerapan model guided discovery learning menunjukkan hasil yang cukup maksimal. Dibuktikan dengan hasil dari aktivitas peserta didik pada siklus II memberikan hasil ynag cukup baik serta memuaskan.

\section{KESIMPULAN}

Berdasarkan hasil analisis dan pembahasan maka dapat disimpulkan bahwa motivasi belajar geografi peserta didik kelas XII IPS 2 SMA Negeri 9 Kota Jambi mengalami peningkatan setelah diterapkan Model guided discovery learning dengan indikasi rerata motivasi belajar peserta didik sebelum menggunakan model guided discovery learning adalah 40,67 dengan skor maksimal yang mungkin diraih adalah 100. Kemudian meningkat setelah penerapan model guided discovery learning pada siklus I sebesar 63,267 termasuk dalam kategori sedang, dan pada siklus II sebesar 75,33 juga termasuk dalam kategori sedang dengan persentase peningkatan $13,79 \%$. Hasil observasi aktivitas peserta didik dalam proses belajar mengajar juga terjadi peningkatan, pada siklus I pertemuan pertama sebesar 60,14\% kemudian mengalami peningkatan pada pertemuan kedua sebesar 68,88\%. Pada siklus II pertemuan pertama sebesar $70,83 \%$ dan mengalami perubahan pada pertemuan kedua sebesar $78,47 \%$ termasuk dalam kategori "sangat aktif".

\section{DAFTAR PUSTAKA}

Adhim, A. Y. (2015). Penerapan model pembelajaran guided discovery dengan kegiatan laboratorium untuk meningkatkan motivasi belajar siswa kelas X SMA pada materi suhu dan kalor. Inovasi Pendidikan Fisika, 4(3).

Aini, E.N. (2011). Penerapan Guided Discovery Untuk Meningkatkan Motivasi Belajar Dan Kemampuan Komunikasi Ilmiah Siswa. Skripsi. Semarang: Fakultas Matematika dan Ilmu Pengetahuan Alam Universitas Negeri Semarang. 
Aritonang, K. T. (2008). Minat dan motivasi dalam meningkatkan motivasi belajar siswa. Jurnal pendidikan penabur, 7(10), 11-21.

Dimyati dan Mudjiono. (2006). Belajar dan Pembelajaran. Jakarta: PT Raja Grafindo Persada.

Duhita, S. A., Suprapta, S., \& Hasriyanti, H. (2020). Problematika Guru dalam Pelaksanaan Kurikulum 2013 pada Pembelajaran Geografi. LaGeografia, 18(2), 109-116.

Emda, A. (2018). Kedudukan motivasi belajar siswa dalam pembelajaran. Lantanida Journal, 5(2), 172-182.

Harjanti, D. T. (2014). Penerapan Teknik Peta Pikiran (Mind Map) Untuk Meningkatkan Pemahaman Konsep Geografi Pada Siswa Kelas XI-2 IPS SMAN 1 Rasau Jaya Kabupaten Kubu Raya. Jurnal Geografi Gea, 14(1).

Jacobson, D.A., Eggen, P. \& Kauchak, D. (2009). Methods for teaching. Yogyakarta: Pustaka Pelajar

Kusuma, Z. L., \& Subkhan, S. (2015). Pengaruh Motivasi Belajar dan Kedisiplinan Belajar terhadap Prestasi Belajar Mata Pelajaran Akuntansi Siswa Kelas XI IPS SMA N 3 Pati Tahun Pelajaran 2013/2014. Economic Education Analysis Journal, 4(1).

Mayer, R.E. 2004. Should three be a three-strikes rule againts pure. the american psychological association. American Psychologist Journal. 59(1): 14-19

Nashar. (2004). Peranan Motivasi dan Kemampuan Awal dalam Kegiatan Pembelajaran. Jakarta: Delia Press.

Ningsih, M. P., Hilman, I., \& Guntara, F. (2020). Implementasi Blended Learning Melalui Google Classroom Pada Mata Kuliah Media Pembelajaran Geografi. LaGeografia, 19(1), 1-15.

Nur, B. N. (2018). Penerapan Model Pembelajaran Problem Based Learning (PBL) untuk Meningkatkan Hasil Belajar Geografi Kelas XI IPS 1 SMA Negeri 12 Makassar. LaGeografia. https://doi.org/10.35580/lga.v17i1.7339

Nurjannah, H., Saputro, A., Maddatuang, M., \& Fikri, M. J. N. (2020). Penerapan Model Pembelajaran Treffinger Pada Pembelajaran Geografi. LaGeografia, 19(1), 113-127.

Olufunmilayo, I.O. 2010. Comparative effect of the guided discovery and concept mapping teaching strategies on sss students' chemistry achievement. Humanity \& Social Sciences Journal. 5(1): 01-06

Pratama, F., Firman, F., \& Neviyarni, N. (2019). Pengaruh motivasi belajar siswa terhadap motivasi belajar ipa di sekolah dasar. Edukatif: jurnal ilmu pendidikan, 1(3), 280-286.

PURWATI, R. (2014). Upaya Meningkatkan Keaktifan Siswa Dalam Pembelajaran Geografi Melalui Model Pembelajaran Kooperatif Tipe Student Teams-Achievement Division (Stad) Di Kelas Xi Ips-1 Sma Negeri 1 Rembang (Doctoral dissertation, UNIVERSITAS MUHAMMADIYAH PURWOKERTO).

Purwanto, C. E., \& Nughoro, S. E. (2012). Penerapan model pembelajaran guided discovery pada materi pemantulan cahaya untuk meningkatkan berpikir kritis. UPEJ Unnes Physics Education Journal, 1(1).

Ridsa, A., Sideng, U., \& Suprapta, S. (2020). Efektifitas Penggunaan Media Pembelajaran 3D Hologram dalam Meningkatkan Motivasi Belajar Siswa Di SMA Negeri 2 Majene. LaGeografia, 18(3).

Sardiman. (2011). Interaksi dan Motivasi Belajar Mengajar. Jakarta: Raja Grafindo Persada.

Sulistyowati, N., Widodo, A. T. W. T., \& Sumarni, W. (2012). Efektivitas model pembelajaran guided discovery learning terhadap kemampuan pemecahan masalah kimia. Chemistry in education, $1(2)$.

Suprihatin, S. (2015). Upaya guru dalam meningkatkan motivasi belajar siswa. Jurnal Pendidikan Ekonomi UM Metro, 3(1), 73-82. 